Trakya Eğitim Dergisi

Cilt 10, Sayı 2

May1s 2020,519-536

Geliș Tarihi: 08.10.2019.

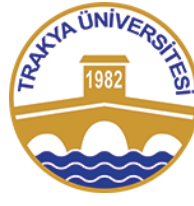

ISSN: 2630-6301

Doi: $10.24615 /$ tred.630965

Araştırma Makalesi/

Research Article
Trakya Journal of Education

Volume 10, Issue 2

May 2020, 516-536

Yayına Kabul Tarihi:03.04.2020

\title{
İlköğretim Matematik Öğretmen Adaylarının Perspektifinden: Niçin Öğretmen Olmak İstedim? Ne Hissediyorum?
}

\section{Why Did I Choose Teaching? How Do I Feel?: The Case of Pre-Service Mathematics Teachers}

\section{Büşra KARTAL ${ }^{1}$, Yasemin KIYMAZ ${ }^{2}$}

ÖZ: Öğretmenlik etkisi hiçbir zaman sona ermeyen bir meslektir ve bireylerin yaşamı üzerinde derin etkiler bırakabilir. Öğretmenlerin mesleklerini severek yapmaları büyük önem taşımaktadır. Öğretmenlik mesleğini içsel nedenlerle tercih edenlerin iç motivasyonlarının yüksek olduğu ve öğrenmeye açık oldukları bilinmektedir. Öğretmenlerin mesleği tercih nedenlerinin belirlenmesi onların mesleğe ilişkin duygu, düşünce ve inançlarını açığa çıkararak öğretmen eğitim programları için planlama ve değerlendirmede yol gösterici olabilir. Bu noktadan hareketle bu çalışmada ilköğretim matematik öğretmen adaylarının öğretmenlik mesleğini tercih nedenleri, matematiğin tercih nedenleri üzerindeki etkisini ve ilköğretim matematik öğretmeni olacak olmanın öğretmen adaylarına ne hissettirdiğinin incelenmesi amaçlanmıștır. Çalıșmanın katılımcıları bir devlet üniversitesinin matematik eğitimi anabilim dalında öğrenim görmekte olan 118 öğretmen adayından oluşmaktadır. Üç açık uçlu soru aracılığıyla toplanan veriler analiz edildiğinde öğretmen adaylarının çoğunlukla içsel ve dıșsal nedenlerle öğretmenlik mesleğini tercih ettikleri görülmüştür. Öğretmen adaylarının yarıya yakını matematiği sevdiği için böyle bir tercih yaptı̆̆ını belirtmiştir. Katılımcıların en çok ifade ettiği duygular mutluluk ve heyecan iken, korku ve endişe hissettiğini belirten öğretmen adayları da olmuştur.

Anahtar sözcükler: Öğretmenlik mesleği, tercih nedeni, ilköğretim matematik öğretmen adayları, duygular

\section{Bu makaleye atı verin /}

Kartal, B. \& Kıymaz, Y. (2020). İlköğretim matematik öğretmen adaylarının perspektifinden: niçin öğretmen olmak istedim? Ne hissediyorum?. Trakya Ĕ̈itim Dergisi, 10(2), 519-536.

\section{Cite this article as:}

Kartal, B. \& Kiymaz, Y. (2020). Why did I choose teaching? how do 1 feel?: the case of pre-service mathematics teachers. Trakya Journal of Education, 10(2), 519-536.

1 Arș. Gör. Dr., Kırșehir Ahi Evran Üniversitesi, e-posta: busra.kartal@ahievran.edu.tr, ORCID ID: 0000-0003-2107-057X

2 Dr. Öğr. Üyesi, Kırşehir Ahi Evran Üniversitesi, e-posta: ykiymaz@ahievran.edu.tr, ORCID ID: 0000-0002-2189-183X

\begin{abstract}
Teaching is a profession whose effect never ends, and which can play a crucial role in individuals' lives. It is of great importance for teachers to do their jobs willingly. It is known that those who prefer teaching profession for internal reasons have high internal motivation and are more open to learning. Determining the reasons for teachers' career choice may reveal their feelings, thoughts and beliefs about the profession and can be a guide for teacher education programs. In this study, it is aimed to examine the reasons of pre-service mathematics teachers' career choice, the effect of mathematics on their choice and how it feels to be a primary school mathematics teacher for prospective teachers. The participants of the study consisted of 118 prospective mathematics teachers from a public university. When the data collected through three open-ended questions were analyzed, it was seen that preservice teachers mostly preferred teaching profession for internal and external reasons. Nearly half of the teacher candidates stated that they made this choice because they liked mathematics. While the most expressed emotions of the participants were happiness and excitement, there were also pre-service teachers who stated that they felt fear and anxiety.
\end{abstract}

Keywords: Teaching profession, career choice, pre-service mathematics teachers, feelings 


\section{EXTENDED ABSTRACT}

\section{Introduction}

Teachers convey their personal feelings, thoughts, and beliefs about a subject to their students consciously or unconsciously (Carter \& Norwood, 1997). Teaching is a profession whose effect never ends and always deeply affects individuals' lives (Smith, 1986). Since the feelings and thoughts of teachers and prospective teachers related to the teaching profession will affect the teaching processes (Özbek, Kahyaoğlu \& Özgen, 2007), the determination of these feelings and thoughts is of great importance in increasing the quality of teacher education (Yenice \& Özden, 2017). One way to determine the pre-service teachers (PSTs)' feelings and thoughts about the teaching profession may be to examine the reasons for their career choice.

The reasons why teachers or PSTs prefer teaching as a profession are divided into different categories by different researchers. Övet (2006) grouped the factors affecting the reasons for a career choice as consciousness, security, ideal, and influence, while Özbek (2007) and Özbek et al. (2007) grouped them as personal, economic and social. The most common group of reasons for a career choice in the literature is altruistic, internal and external factors (Aktürk, 2012; Bastick, 2000; Boz and Boz, 2008, Bursal and Buldur, 2013, Çermik et al., 2010; Papanastasiou and Papanastasiou, 1997; Saban, 2003). In this study, this type of pf categorizing was used, and the characteristics of the different categories of reasons were discussed in detail.

The internal factor is related to the values of the teaching itself and the PSTs' values. This factor includes the love of children, being gifted for education, interest, and enthusiasm for teaching/learning processes (Papanastasiou and Papanastasiou, 1997). The external factor includes the benefits that are related to the teaching profession, and that influences the PSTs to choose teaching (Papanastasiou and Papanastasiou, 1997). Altruism can be defined as the interest for the benefit of another regardless of their interests. Based on this definition, it is seen that altruism incorporates positive social behaviors such as helping, taking responsibility, and donating (İssmen and Yıldız, 2005). The desire to serve people, to be beneficial to the society, to make a positive difference in students' lives, to serve their country, and to advance knowledge was seen as altruistic reasons that affect the choice of the teaching profession (Bastick, 2000; Boz and Boz, 2008; Brown, 1992; Çermik et al. Evans, 1993; Hayes, 1990; Kyriacou \& Coulthard, 2003; Olashinde, 1972; Saban, 2003; Sinclair, 2008).

When the studies conducted with prospective mathematics teachers are examined, it is seen that enough score to enter the faculty of education and the love of mathematics are common ideas that emerged in all studies. This situation can be interpreted as the main factor affecting PSTs' preference is mathematics, even if it is not their first choice. However, it was seen that none of the questions posed to the PSTs were related to the direct effect of mathematics on the career choice in past studies. From this point of view, research problems are determined as follows;

1. What are the reasons for pre-service mathematics teachers to choose a teaching career?

2. What kind of an effect does mathematics have on the career choice of pre-service mathematics teachers?

3. How does the idea of becoming a mathematics teacher make pre-service mathematics teachers feel?

\section{Method}

This study is phenomenological research that aims to examine, understand, and explain preservice teachers' experiences related to why they choose to teach as a career. The participants of the study consisted of PSTs studying in Elementary Mathematics Education of a public university in Central Anatolia. A total of 118 PSTs participated in the study voluntarily.

The data of the study were collected through a questionnaire consisting of open-ended questions. In the questionnaire, there are three questions to which PSTs were asked to answer; (1) What is your reason for choosing mathematics teaching? (2) How did mathematics affect your choice of the teaching profession? And (3) How do you feel when you think you will be a teacher in the future?

When analyzing the data, the codes were firstly determined, and similar codes were taken together to create the categories. These categories were then placed under the internal, external, and altruistic reasons for career choice mentioned in the literature. During the creation of the categories, 
two researchers came together and discussed and agreed on the categories and sub-categories until they reached a consensus. Frequency and percentages were calculated for the categories.

\section{Findings, Discussion, and Conclusion}

The findings show that PSTs choose teaching as a career mostly for internal reasons and then for external and altruistic intentions, respectively. When examining the internal reasons affecting the PSTs' career choice, PSTs' liking or skills related to mathematics or teaching constitute their intrinsic motivation. In terms of the internal codes that PSTs most and least stated, almost half of the participants indicated that they liked mathematics. Similarly, in the studies of İncikabı et al. (2016) and Tataroğlu et al. (2011), liking of mathematics emerged as the most substantial internal reason. Also, loving the subject PSTs choose to teach has emerged as the reason for preferring the teaching (Boz and Boz, 2008; Gürbüz and Sülün, 2004; Sinclair, 2008). The liking of learning mathematics is seen as the least effective internal reason.

One-quarter of the PSTs stated that they chose to teach because their university placement scores were enough for this career. This rate should not be underestimated. Although the first choice of some participants is not teaching, it is thought that they make this choice because they like mathematics. Also, the status of appointment and being considered as an advantageous profession among other professions affected the PSTs' career choice.

It is thought that the PSTs consciously prefer this profession, and they are expected to teach well and develop themselves with the idea that they have high intrinsic motivation. However, the ratio of PSTs who stated that they prefer this profession for altruistic reasons is quite low compared to those who prefer it for internal and external reasons. This situation can be interpreted as PSTs' focus on individual interests, skills, and goals rather than considering the benefit of society in choosing a profession. It is thought that altruistic reasons may not have come to their minds for the first time because the PSTs answered open-ended questions instead of choosing from pre-determined items. This finding reveals the need for altruistic aspects of teaching in teacher education programs.

Findings related to the second research problem show that mathematics affects the PSTs' career choices positively and greatly. The love of mathematics that supports the results of the first question is the most regular expression. When the answers of the PSTs in the second question are examined, it can be said that the participants whose primary preference is not teaching choose teaching as a career because they love mathematics, believe that they can teach, and think that they will be successful.

The three most expressed emotions are happiness, excitement, and beautiful feelings. The most expressed negative feeling was expressed as anxiety-fear. According to these findings, it is seen that PSTs are happy with their choices, but some are worried about what kind of a teacher they will become.

\section{GíRiş}

Öğretmenlik, etkisi hiçbir zaman sona ermeyen ve bireylerin yaşamını derinden etkileyen bir meslektir (Smith, 1986). Öğretmenler bir konuya dair kişisel duygu, düşünce ve inançlarını bilinçli ya da bilinçsiz bir şekilde konuyu anlatırken öğrencilerine aktarmaktadırlar (Carter \& Norwood, 1997). Öğretmenlerin ve öğretmen adaylarının mesleğe ilişkin duygu ve düşünceleri öğretim süreçlerini etkileyeceği için (Özbek, Kahyaoğlu \& Özgen, 2007) bu duygu ve düşüncelerin belirlenmesi öğretmen niteliğini arttırmada büyük önem taşımaktadır (Yenice \& Özden, 2017). Öğretmen adaylarının mesleğe ilişkin duygu ve düşüncelerinin belirlenmesinin bir yolu öğretmenlik mesleğini tercih nedenlerinin incelenmesi olabilir.

Bireylerin meslek tercihi, seçmek istedikleri mesleğin gereklilikleri ile yetenekleri arasındaki uyuma dair düşünceleri ile ilgilidir (Ginzberg, Gingsburg, Axelrad \& Herma, 1951). Bu noktadan hareketle, öğretmen adaylarının öğretmenlik mesleğini yapabilecek yeterliklere sahip olduklarını düşünerek eğitim fakültelerini tercih etmeleri beklenebilir. Öğretmenlik mesleğinin bireylerin, toplumun ve bir ülkenin sosyalleşmesi, gelişmesi ve nitelikli hale gelmesinde aldı̆̆ rol göz önüne alındığında öğretmenlik mesleğini tercih eden bireylerin tercih nedenlerinin incelenmesi halen güncel bir ilgi alanı olarak araştırmacıların ilgisini çekmektedir (Çermik, Doğan \& Şahin, 2010; Kartal \& Taşdemir, 2012). Öğretmen adaylarının öğretmenlik mesleğini niçin tercih ettiklerinin incelenmesi öğretmen adaylarının öğrenmeye açık olup olmadıklarının (Aktürk, 2012; Yılmaz \& Doğan, 2015), 
öğretmenlik mesleğinin bir gerekliliği olarak görülen mesleğe ilgi duyma ve olumlu tutum besleme ve mesleği gerçekleștirebileceğine ilişkin inanca sahip olup olmadıklarının (İncikabı, Mercimek, Biber, \& Serin, 2016) belirlenmesinde ve nitelikli öğretmen yetiştirilmesinde (Kartal \& Taşdemir, 2012; Taratoğlu, Özgen \&Alkan, 2011) büyük önem taşımaktadır.

Öğretmen adayları veya öğretmenlerin bir meslek olarak öğretmenliği tercih etme nedenleri farklı araştırmacılar tarafindan farklı kategorilere ayrılmışıtır. Övet (2006) tercih nedenlerini etkileyen faktörleri bilinç, güvence, ideal ve etkilenme; Özbek (2007) ve Özbek ve diğerleri (2007) kişisel, ekonomik ve sosyal olarak gruplandırırken Kartal ve Taşdemir (2012) ise zorunluluk ve isteklilik olarak gruplandırmışlardır. Literatürde tercih nedenlerinin en yaygın gruplandırılması ise, içsel, dışsal ve özgeci etkenler şeklindedir (Aktürk, 2012; Bastick, 2000; Boz \& Boz, 2008, Bursal \& Buldur, 2013, Çermik vd., 2010; Papanastasiou \& Papanastasiou, 1997; Saban, 2003). Bu araştırmada da bu gruplandırma kullanılmış ve farklı grupların özellikleri detaylı bir biçimde ele alınmıştır.

İçsel faktör öğretimin kendisi ve öğretmen adaylarının kendileri için sahip oldukları değerler ile ilgilidir. Bu faktör çocuk sevgisi, öğretim için doğuştan yetenekli olmak, öğretme/öğrenme süreçlerine duyulan ilgi ve heyecanı içermektedir (Papanastasiou \& Papanastasiou, 1997). Mesleği sevmek, çocukları sevmek ve onlarla çalışma isteği, ilgi duymak ve öğretmenlik yapabilecek beceriye sahip olduğunu düşünmek, öğretmenlik mesleğinin öğretmen adaylarının hayalinin olması, kültür arttırma arzusu, kariyer yapma arzusu, kişisel bilgi ve uzmanlığını paylaşma isteği ve olumlu bir öğrenme ortamı oluşturma literatürde öğretmenlik mesleğini etkileyen içsel nedenler olarak öne çıkmaktadır (Aktürk, 2012; Argun, 2003; Çermik vd., 2010; Evans, 1993; Özder, Konedralı \& Zeki, 2010; Sinclair, 2008). Başka bir deyişle, içsel faktör bireylerin kendi duygu, düşünce ve inançları ile ilgilidir ve kendileri dışındaki herhangi bir faktörden etkilenmediği söylenebilir.

Dışsal faktör ise öğretmenlik mesleği ile ilgili olan ve öğretmen adaylarının bu mesleği seçmelerini etkileyen faydaları içermektedir (Papanastasiou \& Papanastasiou, 1997). Bu faktöre örnek ise iş garantisinin olması, tatili çok olması, sosyal güvence ve atamasının iyi olması, aile isteği, üniversiteye yerleştirme puanının ancak bu bölüme yetmesi, ailede hiç öğretmen olmaması, mesleğin yüksek düzeyde stresli bir iş olmayışı, mesleğin toplumda saygın bir yerinin olması ve öğretmenlerinden etkilenme şeklindeki görüşlerdir (Aktürk, 2012; Boz \& Boz, 2008; Bastick, 2000; Brown, 1992; Çermik vd., 2010; Hayes, 1990; Kyriacou \& Coulthard, 2000; Olashinde, 1972; Özder vd., 2010; Sinclair, 2008; Yong, 1995). Dışsal faktörler ise çoğunlukla bireylerin kendileri ile ilgili olmadığı halde bireyleri motive eden dış etken veya sebepler olarak ele alınabilir.

Özgecilik kendi çıkarını gözetmeksizin bir başkasının yararı için duyulan ilgi olarak tanımlanabilir. Bu tanımdan yola çıkılarak özgeciliğin yardım etme, sorumluluk üstlenme ve bağış yapma gibi olumlu sosyal davranışları bünyesinde barındırdığı görülmektedir (İşmen \& Yıldız, 2005). İnsanlara hizmet etme ve topluma faydalı olma isteği, öğrencilerin hayatlarında olumlu bir fark yaratmak, ülkesine hizmet etmek ve bilgiyi ilerletmek öğretmenlik mesleğini tercih etmeyi etkileyen özgeci nedenler olarak karşımıza çıkmaktadır (Bastick, 2000; Boz \& Boz, 2008; Brown, 1992; Çermik vd., 2010; Dawson, 2007; Evans, 1993; Hayes, 1990, Kyriacou \& Coulthard, 2000; Olashinde, 1972; Saban, 2003; Sinclair, 2008). Özgeciliğin bünyesinde barındırdığı nedenler göz önüne alındığında toplumumuzda çoğunlukla idealist olarak tanımlayabileceğimiz bireylerin bu nedenlerle öğretmenlik mesleğini tercih edecekleri düşünülebilir.

Öğretmen adayları niçin öğretmenlik mesleğini tercih ettiklerini dile getirirlerken yalnızca özgeci, içsel ya da dışsal nedenler belirtebilecekleri gibi tercihlerinin nedenini açılarken bu kategorilerden herhangi ikisine veya tamamına dâhil olan sebepler de belirtebilirler. Başka bir deyişle, öğretmen adaylarının mesleği tercih nedenleri içsel, dışsal ve özgeci kategorilerinden en az birinin veya daha fazlasının içine girmektedir (Bastick, 2000). Öğretmenler toplumsal bir sorumluluk görevini de üstlendiği için bu mesleği tercih eden bireylerin dışsal etkenlerden ziyade içsel etkenleri ön planda tutarak bilinçli bir tercih yapmaları beklenmektedir (İncikabı vd., 2016). Nitekim içsel nedenlerden dolayı öğretmenlik mesleğini tercih eden öğretmen adaylarının öğrenmeye daha açık, öğrenmeye ilişkin beklentilerinin yüksek ve kaygılarının düşük seviyede olduğu görülmüştür. Bu öğretmen adaylarının içsel motivasyonunun yüksek olduğu söylenebilir (Aktürk, 2012). İçsel motivasyonu yüksek bireylerde merak, bilme ihtiyacı, yeterli olma ve gelişme arzusunun ortaya çıktığı görülmektedir (Akbaba, 2006) ki bu özelliklerin bir öğretmenin mesleki gelişimi için büyük öneme sahip olduğu söylenebilir. 
Öğretmenlerin sahip olması gereken nitelikler mesleki ve kişisel yeterlikler olarak ikiye ayrılmaktadır. Mesleki yeterlikler öğretmen eğitim programları müfredatıyla verilen genel kültür, konu alan bilgisi ve öğretmenlik meslek bilgi ve becerilerini içermektedir. Kişisel yeterlikler ise öğretmenliğin gerektirdiği örnek olma özelliklerini ve mesleğe yatkınlıklarını içermektedir (Aydın \& Sağlam, 2012). Millî Eğitim Bakanlı̆̆ı (MEB) tarafından 2017 yılında yayınlanan "Öğretmenlik Mesleği Genel Yeterlikleri" kitapçığında "Tutum ve Değerler" bir yeterlik olarak belirlenmiş ve mesleki bilgi ve becerinin yanı sıra tutumların da öğretmenlik mesleği için önemi ortaya koymuştur. Öğretmenlik mesleğini sevdiği için tercih edenlerin iş garantisi ve aile isteği gibi dışsal nedenlerden dolayı tercih edenlere nazaran daha olumlu tutumlara sahip oldukları söylenebilir (Gürbüz \& Kışoğlu, 2007; Özder vd., 2010; Sağlam, 2008). Bu durum öğretmenlik mesleğini tercih etme nedenleri ile mesleğe yönelik tutum arasındaki ilişkiye dair bir bakış açısı sunmaktadır.

Öğretmen adaylarının öğretmenlik mesleği ile ilgili ne düşündükleri ve ne hissettiklerinin belirlenmesi de önemlidir (Çarpraz \& Samanc1, 2014; Kartal \& Taşdemir, 2012). Bu sayede öğretim etkinlikleri öğretmen adaylarının mevcut düşünce ve hislerine göre düzenlenerek nitelikli ve mesleğini seven öğretmenlerin yetiştirilmesi sağlanabilir (Özbek vd., 2007). Öğretmen adaylarının öğretmenlik mesleğine ilişkin hisleri çoğunlukla heyecan, özgüven, hayal kırıklığı ve tedirginlik (Çarpraz \& Samanc1, 2014; Yenice \& Özden, 2017) olarak ortaya çıksa da öğretmen adayları öğretmenliğin saygın bir meslek olmanın yanı sıra sorumluluk ve fedakârlık duygularını da gerektirdiğini ifade etmişlerdir (Özbek vd., 2007). Mesleğe ilişkin duygular mesleğe yönelik tutumun belirlenmesi ve geliştirilmesinde önemli bir rol oynayabilir. Öğretmenlerin tutumlarının öğrencileri üzerindeki etkisi göz önüne alındığında (Ford, 1994) ise öğretmenlik mesleğini tercih etme nedenlerinin ve öğretmenlik mesleğine yönelik duyguların belirlenmesi tutumların geliştirilmesi ve iyileştirilmesi için yapılacak düzenlemeleri belirleme ve planlama için iyi bir başlangıç noktası olabilir. Bu araştırmada, ilköğretim matematik ögretmen adaylarının mesleği tercih nedenleri, matematiğin bir bilim olarak mesleği tercih etme nedenleri üzerindeki etkisi ve mesleğe yönelik duygularının incelenmesi amaçlanmıştır.

\section{Matematik Öğretmen Adaylarının Öğretmenlik Mesleğini Tercih Nedenleri}

Öğretmenlik mesleği öğretim etkinliklerinin ve programının kalitesi ve denetlenmesi, öğretim teknolojileri ve yönetimle ilgili olduğu kadar bu mesleği yapmak isteyen bireylerin görüş ve davranışları ile de ilgilidir (Özbek vd., 2007). Öğretmenlerin öğrencilerine nası1 rehberlik edeceklerine ilişkin performansları öğretmenlik mesleğine ilişkin görüşlerinden etkilenmektedir. Öğretmen adaylarının öğretmenlik mesleğine ilişkin görüşleri bu mesleği tercih etme nedenleri ve öğretmen olma fikrinin öğretmen adaylarına hissettirdikleri aracılığıyla incelenebilir. Bu çalışmada ilköğretim matematik öğretmen adaylarının öğretmenlik mesleğini tercih nedenleri ve hisleri incelendiği için bu bölümde ilköğretim matematik öğretmen adaylarının tercih nedenleri ile ilgili yapılmış çalışmalardan (Biber, 2013; Boz \& Boz, 2008; Dawson, 2007; İncikab1 vd., 2016, Ngoepe, 2014; Özbek vd. 2007; Tataroğlu vd., 2011; Yılmaz \& Doğan, 2015) bahsedilecektir.

Özbek ve diğerlerinin (2007) çalışmasına katılan 150 öğretmen adayının öğretmenliğin fedakârlık ve sorumluluk gerektiren bir meslek olduğunu düşündükleri ancak bu mesleği yapmaktan mutlu olmayanların da çoğunlukla olduğu ve bu çalışmaya katılan matematik öğretmen adaylarının büyük çoğunluğunun idealindeki mesleğin öğretmenlik olmadığı sonucuna ulaşılmıştır. Diğer çalışmalar incelendiğinde ise matematik öğretmen adaylarının bir meslek olarak niçin öğretmenliği tercih ettiklerine ilişkin gerekçeleri şu şekilde belirlenmiştir;

- Matematiği sevme (Biber, 2013; Boz ve Boz, 2008; Dawson, 2007; İncikabı vd., 2016; Ngoepe, 2014; Tataroğlu vd., 2011),

- Matematik öğretmenini sevme (Boz ve Boz, 2008; Dawson, 2007; İncikabı vd., 2016; Yılmaz ve Doğan, 2015),

- Mecburiyet/sınav sistemi (Boz ve Boz, 2008; İncikabı vd., 2016; Yılmaz ve Doğan, 2015; Tataroğlu vd., 2011),

- Matematik öğretmeyi sevme (Biber, 2013; Boz ve Boz, 2008; Ngoepe, 2014),

- Öğretmenlerin toplumda sayg1 görmesi (Boz ve Boz, 2008; İncikabı vd., 2016; Y1lmaz ve Doğan, 2015)

- Öğretmenliği uygun bir meslek olarak görme (İncikabı vd., 2016; Y1lmaz ve Doğan, 2015; Tataroğlu vd., 2011

- İyi meslek koşulları (Boz ve Boz, 2008, Dawson, 2007; Yılmaz ve Doğan, 2015) 
- Öğrencilerin hayatında bir farklılığa neden olma isteği (Dawson, 2007; Yılmaz ve Doğan, 2015)

- Çocukları sevme (Dawson, 2007)

- Matematikteki geçmiş başarılar (Dawson, 2007)

- Matematiği önemli bir ders olarak görme (Ngoepe, 2014)

- Matematiği anladığı için matematikle uğraşmaktan memnun olmak (Ngoepe, 2014)

- Tatilin uzun olmasi (Boz ve Boz, 2008)

Matematik öğretmen adayları ile yapılan çalışmalar incelendiğinde matematik öğretmenini ve matematiği sevmenin en fazla ortaya çıkan fikir olduğu görülmektedir. Ayrıca puanının bu bölüme yetmesinden kaynaklı mecburiyet içerisinde olanların da oldukça fazla olduğu söylenebilir. Bu durum öğretmen adaylarının ilk tercihi öğretmenlik olmasa da matematiği sevmelerinin bu bölümü seçmelerini etkileyen temel bir faktör olduğu şeklinde yorumlanabilir. Ancak öğretmen adaylarına yöneltilen soruların hiçbirinde matematiğin meslek tercih nedenleri üzerindeki doğrudan etkisinin sorulmadığ görülmüş ve öğretmen olmaya ilişkin matematik öğretmen adaylarının duygularına dair bulguların az olduğu sonucuna ulaşılmıştır. Bu noktadan hareketle araştırma problemleri şu şekilde belirlenmiştir; nelerdir?

1. İlköğretim matematik öğretmen adaylarının öğretmenlik mesleğini tercih etme nedenleri

2. İlköğretim matematik öğretmen adaylarının öğretmenlik mesleğini tercih etmesinde matematiğin nasıl bir etkisi bulunmaktadır?

3. Gelecekte ilköğretim matematik öğretmeni olma fikri öğretmen adaylarına ne hissettirmektedir?

\section{YÖNTEM}

\section{Araştırmanın Modeli}

İlköğretim matematik öğretmen adaylarının bir meslek olarak matematik öğretmenliğini niçin tercih ettiklerini incelemeyi, anlamayı ve açıklamayı amaçlayan bu çalışma nitel bir araştırmadır. Nitel araştırma desenleri belirlenen araştırma problemlerine cevap vermek için katılımcıların görüşlerini inceleyerek metin veya görüntülerden oluşan verileri toplama, analiz etme ve raporlaştırma süreci olarak tanımlanabilir (Plano Clark \& Creswell, 2015). Bu araştırmada nitel araştırma desenlerinden fenomenoloji kullanılmıştır. Bu seçimin nedeni ise katılımcıların bir meslek olarak öğretmenliği seçme deneyimlerinin katılımcı ifadeleriyle incelenmek istenmesidir (Creswell, 2007). Katılımcıların bir meslek olarak öğretmenliği seçmelerini etkileyen faktörlerin ve seçim sonucu hislerinin açığa çıkarılması ile meslek seçimlerini nasıl deneyimlediklerinin betimlenmesi amaçlanmaktadır (Moustakas, 1994).

\section{Çalışma Grubu/ Evren- Örneklem}

Çalışmanın katılımcıları Orta Anadolu'da bir devlet üniversitesinin Matematik Eğitimi anabilim dalında öğrenim gören öğretmen adayları arasından seçkisiz örnekleme tekniklerinden tabakalı örnekleme kapsamında belirlenmiştir (Büyüköztürk, Çakmak, Akgün, Karadeniz, \& Demirel, 2010). Katılımcılar her bir sınıf seviyesinden katılım sağlanacak şekilde seçilmiştir. Tabakalı örneklemede, evrende yer alan alt tabakalar göz önünde bulundurularak örneklem üzerinde çalışılmaktadır. Bu sayede, araştırma verilerinin evreni temsil etme gücünün artması sağlanabilir (Yıldırım \& Şimşek, 2008). Tabakalı örnekleme kapsamında tüm sınıflardan öğretmen adayı katılımı sağlanarak çalışmanın bulgularının ilköğretim matematik öğretmenliği programında öğrenim gören öğretmen adaylarını temsil etmesi amaçlanmıştır. Çalışmaya gönüllülük esasına dayalı olarak toplam 118 öğretmen adayı katılmıştır. Öğretmen adayı sayılarının sınıflara göre dağılımları Tablo 1'de verilmiştir.

Tablo 1. Katılımcı öğretmen adaylarının sinıflara göre dă̆ıllımı

\begin{tabular}{cccccc}
\hline & 1. Sinıf & 2. Sinıf & 3. Sinıf & 4. Sinıf & Toplam \\
\hline Öğretmen Adayı Sayısı & 28 & 33 & 26 & 31 & 118 \\
\hline
\end{tabular}

\section{Veri Toplama Aracı}


Fenomenoloji araştırmalarında veriler derinlemesine görüşmeler veya açık uçlu sorulardan oluşan yarı yapılandırılmış görüşme formlarıyla toplanabilir (Christensen, Johnson \& Turner, 2011; Creswell, 2007; van Manen, 1990). Çalışmanın verileri, açık uçlu sorulardan oluşan yazılı bir görüşme formu aracılığıyla toplanmıştır. Literatürde öğretmenlik mesleğini tercih nedenleri ile ilgili çalışmalarda öğretmenlik yapılacak branşın sevilmesinin en sık ortaya çıkan nedenlerden biri olduğu görülmüştür. Ancak giriş bölümünde bahsedildiği gibi matematik öğretmen adaylarının bir meslek olarak öğretmenliği tercih etmesi ile ilgili çalışmalarda, matematiğin tercih nedeni üzerindeki etkisine ilişkin bir sorunun olmaması dikkat çekmiştir. Bu noktadan hareketle yazılı görüşme formunda öğretmen adaylarına "Matematik öğretmenliğini tercih etme nedeniniz nedir?", “Öğretmenlik mesleğini seçmenizde matematiğin nasıl bir etkisi oldu?" ve "İleride bir matematik öğretmeni olacağınızı düşünmek size neler hissettiriyor?" soruları yöneltilmiştir. Açık uçlu yazılı görüşme formu öğretmen adaylarına uygulanmadan önce iki matematik eğitimcisinden bu soruların araştırmanın amacı için uygun olup olmadığına ilişkin fikir alınmıştır. Ardından her sınıftan bir öğretmen adayıyla pilot görüşme yapılmış ve öğretmen adaylarının soruları sesli bir biçimde okumaları ve cevaplandırmaları istenmiştir. Bu süreç sesli düşünme tekniği olarak da isimlendirilmektedir (Bowles, 2010). Pilot görüşmeye katılan öğretmen adayları verilerin toplanması aşamasında çalışmaya dahil edilmemiştir.

Veriler sınıf ortamında kalem-kâğıt aracılığıyla toplanmıştır. Öğretmen adaylarına verdikleri cevapların gizli tutulacağ 1 , araştırma dişında bir amaçla kullanılmayacağ 1 ve not ile değerlendirilmeyeceği belirtilmiştir. Öğretmen adaylarının cevaplarında samimi olmalarını sağlamak amacıyla yazılı görüşme formuna isim yazmamaları hatırlatılmıştır. Ayrıca, öğretmen adaylarına veri toplama aracını tamamlamaları için süre kısıtlamasında bulunulmamıştır.

\section{Verilerin Toplanması ve Analizi}

Açık uçlu sorular aracılığıyla toplanan veriler içerik analizi yapılarak yorumlanmaya çalışılmıştır. Verilerin analizine başlamadan önce öğretmen adaylarının doldurdukları yazılı görüşme formları numaralandırılmıştır. Numaralandırma yapılırken ilk olarak öğretmen adaylarının sınıfları yazılmış ve ardından her sınıf kendi içinde sırasıyla numaralandırılmıştır. Örneğin "2-10" ikinci sınıfta 10 numaralı öğretmen adayını temsil etmektedir. Araştırmacılardan biri öğretmen adaylarının verdikleri cevapları Excel programında bir tabloya yerleştirmiş, aynı cevapları veren öğretmen adaylarını tabloda belirtmiştir. Veriler analiz edilirken öncelikle kodlar ve ardından birbirine benzer kodların oluşturduğu alt kategoriler belirlenmiştir. Ardından bu alt kategoriler literatürde belirtilen içsel, dışsal, ve özgeci ana kategorilerinin altına yerleştirilmiştir. Ana kategoriler önceden belli olduğu için tümdengelimsel bir analiz yaklaşımı çerçevesinde içerik analizi yapılıış̧ır. Alt ve ana kategorilerin oluşturulması aşamasında iki araştırmacı verileri birbirinden bağımsız analiz ettikten sonra bir araya gelmiş ve fikir birliği sağlanana kadar tartışarak ana kategoriler ve alt kategorilerde uzlaşma sağlanmıştır (Miles \& Huberman, 1994). İki araştırmacının verileri bağımsız olarak analiz etmeleri sonucunda kodlayıcılar arası güvenirlik (Güvenirlik= [Görüş Birliği/ Görüş Birliği + Görüş Ayrıllı̆̆1] x 100) 0.85 olarak hesaplanmıştır. Elde edilen kategoriler için ifade edilme sıklığı ve yüzdeleri hesaplanmışır. Bazı öğretmen adaylarının cevapları birden fazla kategoride yer aldığından kategorilerdeki frekansların toplamı katılımcı sayısından fazla olarak bulunmuştur. Bir kategorinin ifade edilme yüzdesi, kategorinin frekansının toplam ifade sayısına bölünmesiyle belirlenmiştir.

Araştırma bulgularının nasıl oluşturulduğunun detaylı bir biçimde açılanması ve bulgulara ilişkin doğrudan katılımcı alıntılarının verilmesi nitel araştırmalarda geçerliğin önemli ölçütleri arasında yer almaktadır (Yıldırım \& Şimşek, 2008). Verilerin araştırmacılar tarafından birbirinden bağımsız analiz edilmesi ve ardından analizler için görüş birliğine varılması süreci ise iç güvenirlik açısından büyük önem taşımaktadır.

\section{BULGULAR}

$\mathrm{Bu}$ bölümde üç araştırma problemine ilişkin cevaplar üç ayrı başlık altında verilmiştir. $\mathrm{Bu}$ araştırmada birinci araştırma problemine ilişkin bulgular yapılandırılırken içsel, dışsal ve özgeci tercih nedenleri ana kategorileri altında benzer kodların bir araya gelerek oluşturduğu alt kategoriler de oluşturulmuştur. İkinci araştırma probleminde ise matematiğin etkisi yine içsel, dışsal ve özgeci faktörler göz önüne alınarak bulgular yapılandırılmıştır.

\section{Öğretmen Adaylarının İlköğretim Matematik Öğretmenliği Tercih Etme Nedenleri}


Öğretmenlik mesleğini tercih etme nedenlerinin sorulduğu birinci soruya öğretmen adaylarının verdikleri cevaplar kodlanmış ve bazı öğretmen adaylarının cevaplarında birden fazla kod olduğu görülmüştür. Kodların toplam sayısı 214 olarak belirlenmiştir. Literatürde olduğu gibi bu çalışmada da kodlar "içsel, dışsal ve özgeci" olmak üzere üç ana kategoride toplanmıştır. Bu kategorilerin altına yerleştirilen kodlar incelendiğinde bu kodların da kendi içinde gruplanabileceği fark edilmiştir. Örneğin içsel nedenler kategorisinde yer alan kodlar incelendiğinde bunlardan bazılarının matematikle ilgili, bazılarının ise öğretmenlik mesleği ile ilgili olduğu görülmüştür. Bu iki kategoride de sevgi odaklı ya da beceri odaklı gerekçelerle karşılaşılmıştır. Öğretmen adayları ya matematiği/öğretmenliği sevdiklerini ya da matematikte/öğretmenlikte yeterli kapasiteye sahip olduklarını belirtmişlerdir. $\mathrm{Bu}$ nedenle de ana kategorilerin (içsel, dışsal, özgeci) altında alt kategorilerin belirlenmesine karar verilmiştir. İçsel, dışsal ve özgeci ana kategoriler içerisinde alt kategoriler oluşturulmasına önceki çalışmalarda rastlanmamıştır. Öğretmen adaylarının öğretmenlik mesleğini tercih etmelerine neden olan içsel nedenlere ait gerekçelere ilişkin frekans ve yüzdeler Tablo 2'de verilmiştir.

Tablo 2. Öğretmen adaylarının belirttikleri içsel nedenlere ilişkin frekans ve yüzde analizleri

\begin{tabular}{|c|c|c|c|c|c|}
\hline \multicolumn{2}{|c|}{ Alt Kategori } & Kodlar & f & $\begin{array}{c}\% \\
\text { (öğretmen } \\
\text { adayı) }\end{array}$ & \multirow{2}{*}{$\begin{array}{c}\text { Toplam kod } \\
\text { sayısına göre } \\
\text { yüzde }\end{array}$} \\
\hline \multirow{4}{*}{ Matematik } & & Matematiği sevme & 58 & 49,15 & \\
\hline & Sevgi & Matematiği anlatmayı sevme & 5 & 4,24 & \multirow{3}{*}{33,64} \\
\hline & & Matematiği öğrenmeyi sevme & 3 & 2,54 & \\
\hline & $\begin{array}{l}\text { Beceri } \\
\text { odakli }\end{array}$ & Matematikte yetenekli olma & 6 & 5,08 & \\
\hline \multirow{3}{*}{$\underset{\text { Mesleği }}{\text { Ö̆gretmenlik }}$} & Sevgi & Öğretmenlik mesleğini sevme & 14 & 11,86 & \multirow{3}{*}{14,95} \\
\hline & odakl1 & Çocuk sevgisi & 4 & 3,39 & \\
\hline & $\begin{array}{l}\text { Beceri } \\
\text { odakl1 }\end{array}$ & Öğretmenliği yapabileceğini düşünme & 14 & 11,86 & \\
\hline Toplam & & & & & 48,60 \\
\hline
\end{tabular}

Tablo 2'de görüldüğü üzere öğretmen adaylarının belirttikleri tercih nedenlerinin $\% 48,6$ 's1 içsel nedenlerden oluşmaktadır. Öğretmen adaylarının ifadelerinin \%33,64'ü matematik kaynaklı, \%14,95'i ise öğretmenlik mesleği kaynaklı gerekçelerdir. İçsel nedenlere ilişkin gerekçeler incelendiğinde öğretmen adaylarının mesleği tercih etmelerinde öğretmenlik mesleğinden ziyade matematikten etkilendikleri söylenebilir. Matematik kaynaklı içsel nedenlerden matematik sevgisi odaklı kodlardan "matematiği sevme" kodu öğretmen adaylarının \%49,15'inin, "matematiği anlatmayı sevme" \%4,24'ünün ve "matematiği öğrenmeyi sevme" ise \%2,54'ünün ifadelerinde yer almıştır. Beceri odaklı alt kategori içindeki tek kod olan "matematikte yetenekli olma" ise öğretmen adaylarının \%5,08'inin ifadelerinde ortaya çıkmıştır.

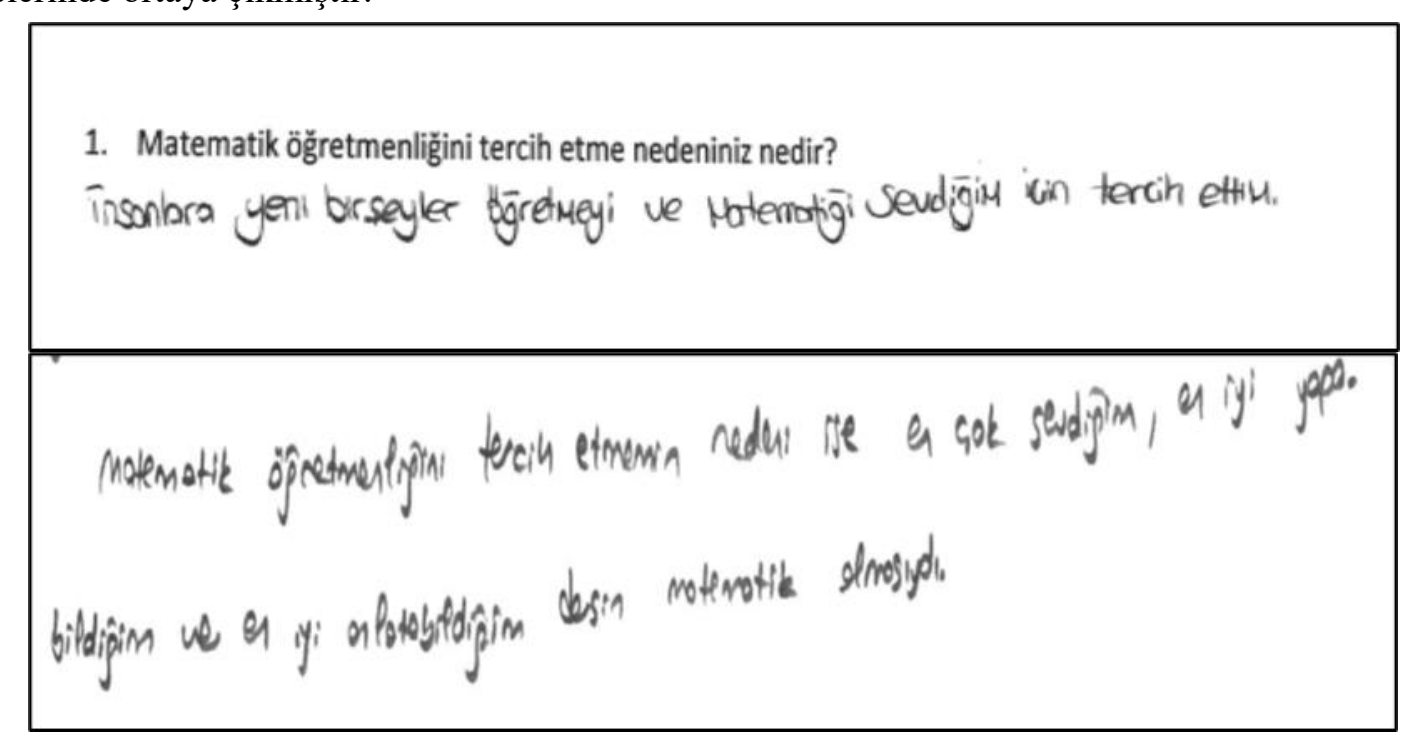


Şekil 1. ÖA 1-26 ve ÖA 4-2 öğretmen adaylarının matematik sevgisi ve becerisi ile ilgili ifadelerinden alıntılar

Şekil 1'de iki öğretmen adayının birinci soruya verdikleri cevaplar görülmektedir. ÖA 1-26'nın ifadesi “matematiği sevme", ÖA 4-2'nin ifadesi ise "matematik becerisi" olarak kodlanmıştır.

Öğretmen adaylarının \%11,86's1 öğretmenlik mesleğini sevdiğini ve \%3,39'u ise çocukları sevdiğini ifade etmiştir. Öğretmenlik mesleğine ilişkin beceri odaklı alt kategorideki tek kod olan "öğretmenliği yapabileceği düşüncesi” kodu ise öğretmen adaylarının \%11,86'sı tarafından dile getirilmiştir.

1. Matematik öğretmenliğini tercih etme nedeniniz nedir?

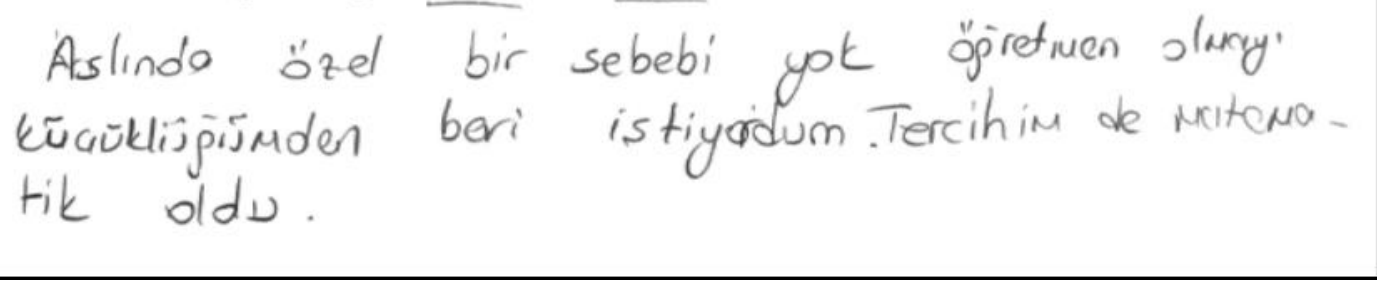

Şekil 2. ÖA 2-5'in öğretmenliği sevme ile ilgili ifadesinden alıntılar

Șekil 2'de öğretmen adayı ÖA 2-6 tercihini etkileyen en önemli etkenin öğretmenliği sevmesi olduğunu ifade etmiş ikinci aşamada öğretmenlik yapacağı branşlar içerisinde matematiği seçtiğini belirtmiştir.

Tablo 3 ise öğretmen adaylarının tercihlerini etkileyen $d$ lşsal nedenlere ilişkin frekans ve yüzde analizini göstermektedir. Öğretmen adaylarının mesleği tercih nedeni olarak belirttikleri ifadelerin \%45,33'ü dışsal nedenlerle ilgilidir. Dışsal nedenlere ilişkin öğretmen adayı ifadeleri incelendiğinde bu nedenlerin "mantıksal seçim, ekonomik açıdan bakış, yönlendirme, sosyal açıdan bakış ve rahatlık açısından bakış" olarak gruplandırılabileceği görülmüş ve dışsal nedenlere ilişkin kodlar bu alt kategoriler altına yerleştirilmiştir. Öğretmen adaylarının öğretmenlik mesleğini tercih etmelerini etkileyen dişsal nedenlerin içerisinde mantıksal seçim kategorisindeki kodlar (puanıma uygun, ögretmen lisesi mezunu olma) en fazla yoğunluğa $(\% 14,95)$ sahip iken "rahat/kolay" ve "tatili bol" gibi kodların oluşturduğu rahatlık açısından bakış kategorisi ise en az yoğunluğa $(\% 3,27)$ sahiptir.

Tablo 3. Öğretmen adaylarının belirttikleri dışsal nedenlere ilişkin frekans ve yüzde analizleri

\begin{tabular}{|c|c|c|c|c|}
\hline Alt Kategoriler & Kodlar & $\mathbf{f}$ & $\begin{array}{c}\% \\
\text { (öğretmen } \\
\text { adayı) }\end{array}$ & $\begin{array}{l}\text { Toplam kod } \\
\text { sayısına göre } \\
\text { yüzde }\end{array}$ \\
\hline Mantıksal Seçim & $\begin{array}{c}\text { Puana uygun } \\
\text { Öğretmen lisesi mezunu olma }\end{array}$ & $\begin{array}{c}30 \\
2\end{array}$ & $\begin{array}{c}25,42 \\
1,69\end{array}$ & 14,95 \\
\hline $\begin{array}{c}\text { Ekonomik açıdan } \\
\text { bakış }\end{array}$ & $\begin{array}{c}\text { Atanma durumu } \\
\text { Diğer mesleklere göre avantajlı } \\
\text { Özel ders imkânı }\end{array}$ & $\begin{array}{c}12 \\
13 \\
2\end{array}$ & $\begin{array}{c}10,17 \\
11,02 \\
1,69\end{array}$ & 12,62 \\
\hline Yönlendirme & $\begin{array}{c}\text { Zorlama (Ailenin tercihi, istemeyerek tercih } \\
\text { etme) } \\
\text { Teşvik (Tavsiye, öğretmen) }\end{array}$ & $\begin{array}{c}13 \\
6\end{array}$ & $\begin{array}{c}11,02 \\
5,08\end{array}$ & 8,88 \\
\hline Sosyal açıdan bakış & $\begin{array}{c}\text { Saygın bir meslek } \\
\text { Bayanlar için ideal meslek }\end{array}$ & $\begin{array}{l}7 \\
5\end{array}$ & $\begin{array}{l}5,93 \\
4,24\end{array}$ & 5,61 \\
\hline $\begin{array}{c}\text { Rahatlık açısından } \\
\text { bakış }\end{array}$ & $\begin{array}{c}\text { Rahat/kolay } \\
\text { Tatili bol }\end{array}$ & $\begin{array}{l}5 \\
2\end{array}$ & $\begin{array}{l}4,24 \\
1,69\end{array}$ & 3,27 \\
\hline & Toplam & & & 45,33 \\
\hline
\end{tabular}

Öğretmen adaylarının tercihlerinde dışsal nedenlerden mantıksal seçim ve ekonomik nedenlerin diğer alt kategorilere göre daha etkili olduğu söylenebilir. Tablo 3 'te öğretmen adaylarının $\% 25,42$ 'sinin "puanlarına uygun" olduğu gerekçesiyle mantıksal seçim yaptıkları görülmektedir (Şekil 3). Bu kod "matematiği sevme" gerekçesinden sonra en yüksek yüzdeye sahip olan kodlamadır. Bu 
durum hedefleri öğretmenlik olmayan ancak mevcut duruma göre mantıksal bir seçim yapma durumunda olan öğretmen adaylarının oranının yaklaşı $\% 25$ olduğunu göstermektedir.

1. Matematik öğretmenliğini tercih etme nedeniniz nedir?

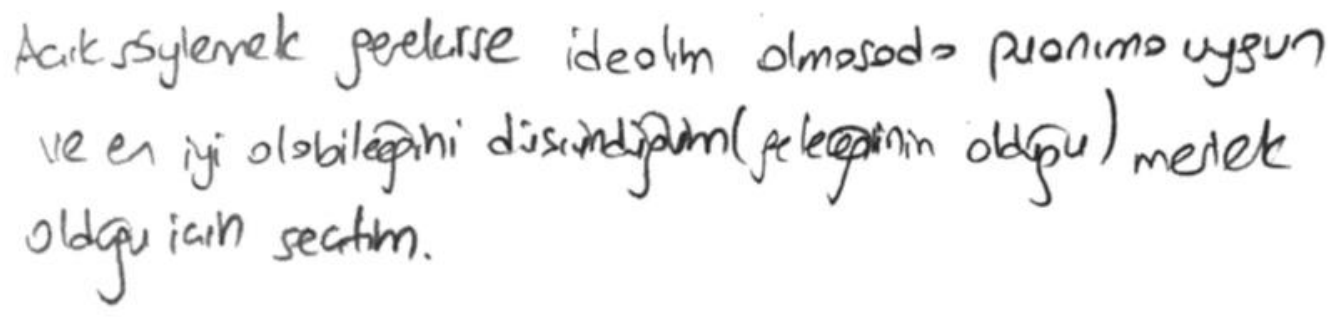

Şekil 3. ÖA 3-23'ün puanına uygun tercih yapması ile ilgili ifadesinden alıntı

Öğretmen adayları ekonomik açıdan bakış alt kategorisinde "atanma durumunun iyi $(\% 10,17)$ " olmasını, "diğer mesleklere göre avantajlı $(\% 11,02)$ " olmasını" ve "özel ders imkânı $(\% 1,69)$ "nın olmasını gerekçe göstermişlerdir.

Yönlendirme ile tercih etme alt kategorisinde iki farklı kodlama bulunmaktadır. Ailesinin isteği ile geldiğini (Şekil 4) veya istemeyerek geldiğini belirten öğretmen adaylarının $(\% 11,02)$ ifadelerinde bir olumsuzluk sezilirken, öğretmenlerinin teşviki veya tavsiyeleri doğrultusunda öğretmenlik mesleğini tercih ettiğini belirten öğretmen adaylarının $(\% 5,08)$ ifadelerinde bir hoşnutsuzluk olmadığ fark edilmiş ve bu nedenle bu alt kategorinin zorlama ve teşvik olarak ikiye ayrılmasına karar verilmiştir.

1. Matematik öğretmenliğini tercih etme nedeniniz nedir?

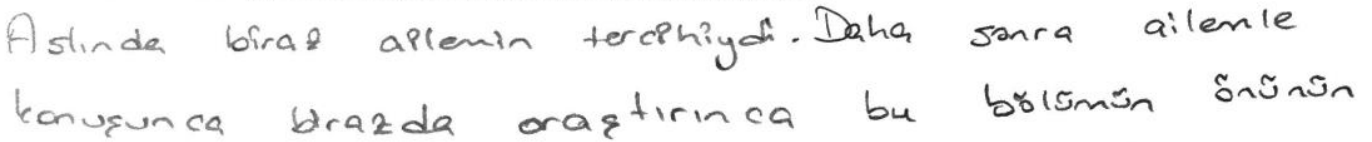

$$
\begin{aligned}
& \text { a aik oldrguns dicsindim. Brezda matematipe olor } \\
& \text { ilgin digeblinrim. }
\end{aligned}
$$

Şekil 4. ÖA 4-8'in meslek tercihinin ailesinin isteği olduğunu belirten ifadesinden alıntı

Sosyal açıdan bakış alt kategorisinde iki kod bulunmaktadır. Öğretmenliğin "saygın bir meslek olması" kodu öğretmen adaylarının \%5,93'ü tarafından dile getirilmişken, "bayanlar için ideal meslek olması" ifadesi ise bir tercih nedeni olarak öğretmen adaylarının \%5,61'i tarafından ifade edilmiştir.

Öğretmenlik mesleğini tercih kategorilerinin en sonuncusu olan özgeci nedenler kategorisine ilişkin frekans ve yüzde analizleri ise Tablo 4 'te verilmiştir.

Tablo 4. Öğretmen adaylarının belirttikleri özgeci nedenlere ilişkin frekans ve yüzde analizleri

\begin{tabular}{cccc}
\hline Gerekçe (kodlar) & f & $\begin{array}{c}\text { \% } \\
\text { (öğretmen } \\
\text { adayı) }\end{array}$ & $\begin{array}{c}\text { Toplam kod sayısına } \\
\text { göre yüzde }\end{array}$ \\
\hline Matematiği sevdirme isteği & 3 & 2,54 & 6,07 \\
Öğretme isteği & 6 & 5,08 & \\
Faydalı olma isteği & 5 & 3,39 & \\
\hline
\end{tabular}

Kişisel yarar gözetmeksizin başkasına yararlı olmayı hedefleyerek tercih yapma ile ilgili kodlamalar oldukça az oranda $(\% 6,07)$ ortaya çıkmıştır (Tablo 4). Özgeci nedenler kategorisinde en fazla "öğretme isteği" $(\% 5,08)$ (Şekil 5) ortaya çıkarken "matematiği sevdirme isteği" $(\% 2,54)$ bu kategoride en az karşılaşılan ifade olmuştur.

Öğretmen Adaylarının Öğretmenlik Mesleğini Tercih Etmesinde Matematiğin Etkisi 
Öğretmen adaylarının ikinci soruya verdikleri cevaplar analiz edildiğinde 154 adet kod ortaya çıkmıştır. Bu kodların \%88,96'sının matematiğin öğretmenlik mesleğini tercih etmeye olumlu etkisinin olduğunu belirten, \%11,04'ünün ise matematiğin etkisinin olmadığını belirten ifadeler olduğu ortaya çıkmışıı (Tablo 5, Tablo 6). Matematiğin olumlu etkisini belirten öğretmen adayı ifadeleri incelendiğinde bunların bir önceki araştırma probleminde olduğu gibi "içsel", "dışsal" ve "özgeci" olarak kategorize edilebileceği görülmüştür. $\mathrm{Bu}$ kategorilere bakıldığında \%68,18'inin içsel, \%16,23'ünün dışsal ve \%1,95'inin özgeci nedenlerden kaynaklı matematik etkisinden bahsettiği sonucuna ulaşılmıştır. 4 öğretmen adayı $(\% 2,6)$ ise hiçbir açıklama yapmadan "olumlu etkisi var" ifadesini kullanmış ve bu öğretmen adayları açıklamasız isimli kategoride bir araya getirilmiştir.

Tablo 5. Öğretmenlik mesleğini tercih etmelerinde matematiğin olumlu etkisi olduğunu belirten öğretmen adaylarının ifadelerine ilişkin frekans ve yüzde analizleri

\begin{tabular}{|c|c|c|c|c|}
\hline Kategoriler & Kodlar & f & $\begin{array}{c}\% \\
\substack{\text { (öğretmen } \\
\text { adayı) }}\end{array}$ & $\begin{array}{c}\text { Toplam kod } \\
\text { sayisına göre } \\
\text { yüzde }\end{array}$ \\
\hline \multirow{6}{*}{ İçsel etki } & Matematik sevgisi & 66 & 55,93 & \multirow{6}{*}{68,18} \\
\hline & Matematik olmasa öğretmenliği seçmezdim & 13 & 11,02 & \\
\hline & Matematikte yetenekli/başarılıyım & 10 & 8,47 & \\
\hline & Matematiği anlatabileceğime inanıyorum & 9 & 7,63 & \\
\hline & Matematiği anlatmayı sevme & 5 & 4,24 & \\
\hline & Matematik öğretmen olma isteğimi arttırdı. & 2 & 1,69 & \\
\hline \multirow{4}{*}{ Dışsal etki } & Öğretmen faktörü (rol model, teşvik) & 9 & 7,63 & \multirow{4}{*}{16,23} \\
\hline & Atanma durumu iyi (ekonomik) & 7 & 5,93 & \\
\hline & Sinav sonucuna etki & 5 & 4,24 & \\
\hline & Matematik önemli bir ders (sosyal) & 4 & 3,39 & \\
\hline Özgeci etki & Öğrencilere matematiği sevdirmek istiyorum & 3 & 2,54 & 1,95 \\
\hline Açıklamasız & Olumlu etkisi var & 4 & 3,39 & 2,60 \\
\hline Toplam & & & & 88,96 \\
\hline
\end{tabular}

Matematiğin içsel nedenlerden kaynaklı etkisinin olduğunu belirten kodlar arasında "matematik sevgisinin" öğretmen adaylarının \%55,93’ü tarafından belirtilmiştir (Tablo 5). Öğretmen adaylarının \%11,02'si “matematik olmasa öğretmenliği seçmezdim" ifadesini kullanmışlardır (Şekil 6). Bu öğretmen adayları için öğretmenliği tercih etmedeki en önemli faktörün matematik olduğu söylenebilir. Benzer olarak "matematik, öğretmen olma isteğimi arttırdı" diyen iki $(\% 1,69)$ öğretmen adayı için de matematiğin önemli bir etkisinin olduğunu söylemek mümkündür. "Matematikte yetenekli/başarılıyım" ya da "matematik anlatabileceğime inanıyorum" kodlarının ise toplam kodlara oranının \%12,33 olduğu görülmekle birlikte bu ifadeler ögretmenliği tercih etmede matematik becerisinin etkisini ortaya koymaktadır. Matematiğin içsel nedenlerden kaynaklı etkisine ilişkin ifade edilen nedenlerin matematik sevgisi veya matematik becerisi ile ilgili olduğu sonucuna ulaşılabilir. 


\section{2. Öğretmenlik mesleğini seçmenizde matematiğin nasıl bir etkisi oldu?}

$$
\text { Matemetic boblim: dmese ogjetwancik secimezdrm }
$$

Şekil 6. ÖA 1-3'ün ikinci soruya verdiği cevap

Tablo 5'te yer alan dışsal etkilerden kaynaklı kodlar incelendiğinde matematiğin daha dolaylı etkisini ortaya koyan ifadelerin olduğu görülmüsşür. Bu kategoride, öğretmen adaylarının \%7,63'ünün “matematik öğretmeni faktörü”nden, \%5,93'ünün "atanma durumunun iyi olması”ndan, \%4,24'ünün "sınav sonucuna etkisi"nden ve \%3,39'unun ise "matematiğin önemli bir ders olması"ndan bahsettiği sonucuna ulaşılmıştır. Bu kategoride matematiğin sınav sonucuna etkisinden bahseden beş öğretmen adayının üniversiteye giriş sınavında matematik başarısının etkisinden bahsettiği anlaşılmıştır.

Matematiğin mesleği tercih etmede özgeci kaynaklı etkileri ise oldukça az oranda $(\% 1,95)$ görülmüştür. Yalnızca üç öğretmen adayı öğrencilere matematiği sevdirmek istediğini belirtmiştir. Bu ifade öğretmenlik mesleğini tercih etmede matematiğin dolaylı etkilerinden biri olarak değerlendirilebilir.

Tablo 6 ise öğretmenlik mesleğini tercih etmede matematiğin etkisi olmadığını belirten öğretmen adaylarının ifadelerine ilişkin frekans ve yüzde analizlerini göstermektedir.

Tablo 6. Öğretmenlik mesleğini tercih etmelerinde matematiğin etkisi olmadığını belirten öğretmen adaylarının ifadelerine ilişkin frekans ve yüzde analizleri

\begin{tabular}{cccc}
\hline Kodlar & f & $\begin{array}{c}\text { \% (öğretmen } \\
\text { adayı) }\end{array}$ & $\begin{array}{c}\text { Toplam kod sayısına } \\
\text { göre yüzde }\end{array}$ \\
\hline Etkisi olmadı-fazla etkisi olmadı & 9 & 7,63 & 5,84 \\
Zaten öğretmen olmak istiyordum & 4 & 3,39 & 2,60 \\
Matematiği sevmeme & 2 & 1,69 & 1,30 \\
İsteyerek tercih etmedim & 2 & 1,69 & 1,30 \\
\hline Toplam & & 11,04 \\
\hline
\end{tabular}

Dokuz öğretmen adayı $(\% 7,63)$ öğretmenlik mesleğini tercih etmelerinde matematiğin etkisi olmadığını dile getirmiştir. Bu ise tüm kodların yalnızca \%5,84 ünü oluşturmaktadır. Dört öğretmen aday1 $(\% 3,39)$ ise "zaten ögretmen olmak istediklerini" belirterek kendileri için öğretmenliğin daha ön planda olduğunu ortaya koymuşlardır (Şekil 7). Matematik öğretmeni adayı olup da matematiği sevmediğini belirten iki öğretmen adayının olması $(\% 1,69)$ bu çalışma içerisindeki dikkat çekici bulgulardan biridir.

\section{2. Öğretmenlik mesleğini seçmenizde matematiğin nasıl bir etkisi oldu?}

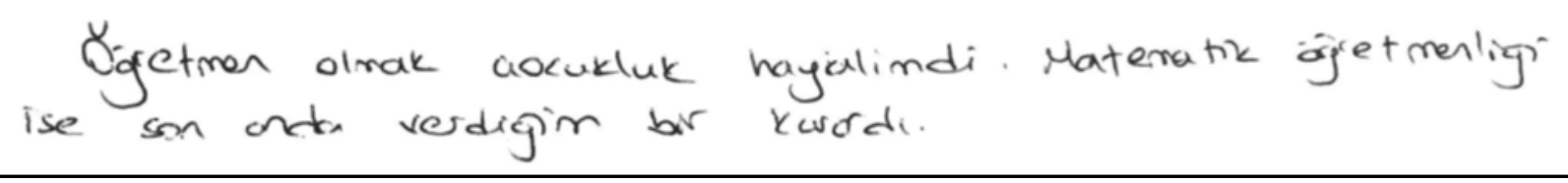

Şekil 7. ÖA 1-14'ün ikinci soruya verdiği cevap

\section{Gelecekte Bir Öğretmen Olmanın Öğretmen Adaylarına Hissettirdikleri}

Araştırmanın üçüncü ve son sorusu olan "İleride bir matematik öğretmeni olacağınızı düşünmek size neler hissettiriyor?" sorusuna öğretmen adaylarının verdikleri cevaplar analiz edildiğinde toplam 147 adet kod elde edilmiştir. Öğretmen adaylarının hissettikleri duyguların frekans ve yüzdeleri Tablo 7 'de verilmiştir.

Tablo 7. Öğretmen adaylarının gelecekte öğretmen olacaklarını düşündükleri zaman hissettikleri duyguların frekans ve yüzde analizleri 


\begin{tabular}{cccc}
\hline & f & \% (öğretmen adayı) & $\begin{array}{c}\text { Toplam kod sayısına göre } \\
\text { yüzde }\end{array}$ \\
\hline Mutluluk & 54 & 45,76 & 36,73 \\
Heyecan & 38 & 32,20 & 25,85 \\
Güzel Hissediyorum & 16 & 13,56 & 10,88 \\
Gurur & 6 & 5,08 & 4,08 \\
Sorumluluk & 5 & 4,24 & 3,40 \\
Sayginlı & 3 & 2,54 & 2,04 \\
Güvence & 3 & 2,54 & 2,04 \\
Umutlu & 3 & 2,54 & 2,04 \\
Hissetmiyorum & 4 & 3,39 & 2,72 \\
Kaygl-korku & 13 & 11,02 & 8,84 \\
Karamsarlık & 1 & 0,85 & 0,68 \\
Bitmişlik & 1 & 0,85 & 0,68 \\
Boğuluyorum & 1 & 0,85 & 0,68 \\
\hline
\end{tabular}

Öğretmen adaylarının hissettikleri duygular tablolaştırılırken ilk önce olumlu duygulara ardından olumsuz duygulara tabloda yer verilmiştir. Kodların \%36,73'ü "mutluluk" (Şekil 8), \%25,85'i "heyecan" ve \%10,88'i "güzel hissediyorum" şeklinde olduğundan öğretmen adaylarının çoğunlukla olumlu duygular içerisinde oldukları söylenebilir. Önemli bir sorumluluğu yerine getireceklerini dile getiren sadece 5 öğretmen adayı olmuştur. Bu da tüm kodların \%3,40’ına karşılık gelmektedir.

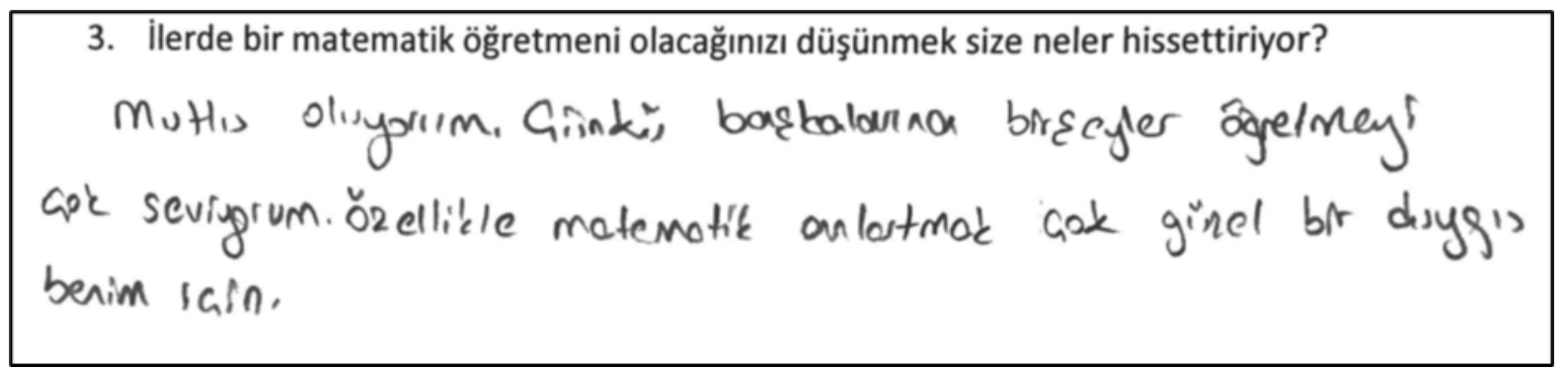

Şekil 8. ÖA 2-16'nın üçüncü soruya verdiği cevap

Tablo 7'de olumlu duyguların yanı sıra olumsuz duygular da olduğu görülmektedir. On üç öğretmen adayı yaşadıkları "korku-kaygı"dan bahsetmiş̧lerdir. Bu öğretmen adaylarından 7'sinin aynı zamanda olumlu duygulara da sahip olduğu görülmüştür (Şekil 9). Korku nedeni olarak matematiğin zorluğu, matematikte her şeyi bilmeme, öğrencilerin matematiğe karş1 önyargıl1 olması, başarılı olamama, atanamama gibi gerekçeler ileri sürmüşlerdir.

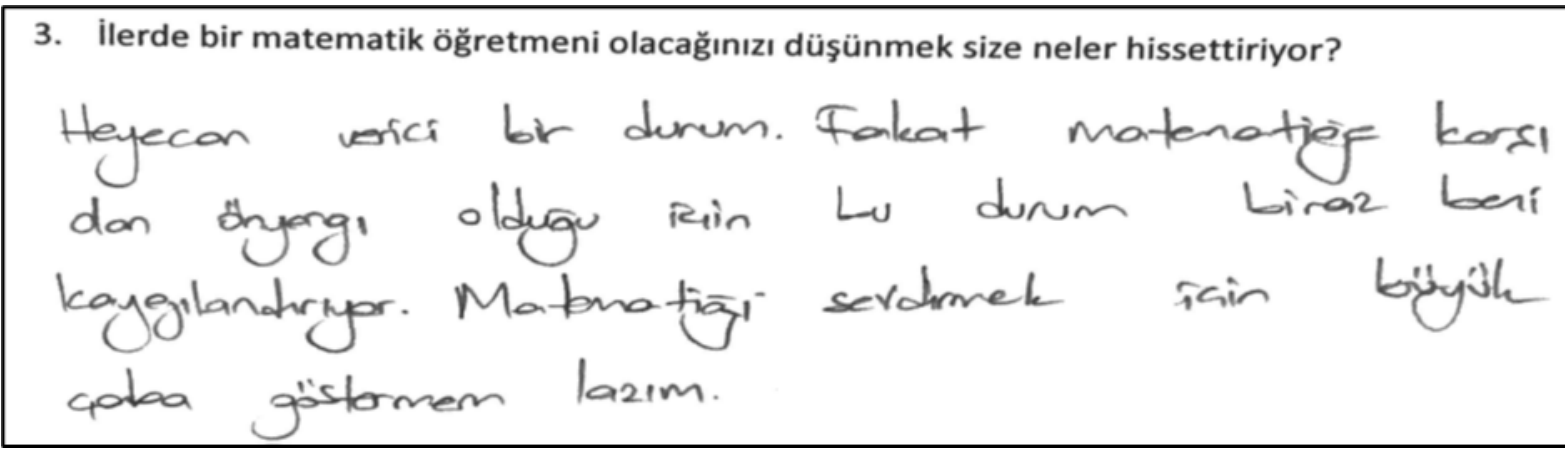

Şekil 9. ÖA 2-18'in üçüncü soruya verdiği cevap

\section{TARTIŞMA, SONUÇ ve ÖNERILER}

$\mathrm{Bu}$ çalışmada ilköğretim matematik öğretmen adaylarının öğretmenlik mesleğini tercih nedenlerinin, matematiğin meslek tercihi üzerindeki etkisinin ve matematik öğretmeni olacak olmanın öğretmen adaylarına hissettirdiği duyguların incelenmesi amaçlanmıştır. Bu amaçla Orta Anadolu'da 
bir eğitim fakültesinin matematik eğitimi programı birinci, ikinci, üçüncü ve dördüncü sınıflarında öğrenim görmekte olan 118 öğretmen adayından üç açık uçlu sorudan oluşan yazılı görüşme formunu cevaplandırmaları istenmiştir. Görüşme formunda öğretmen adaylarına niçin öğretmenlik mesleğini tercih ettikleri, tercihlerinde matematiğin nasıl bir etkisinin olduğu ve öğretmen olmanın öğretmen adaylarına hissettirdikleri sorulmuştur.

Elde edilen bulgular öğretmen adaylarının mesleği çoğunlukla içsel nedenlerle ardından sırasıyla dışsal ve özgeci nedenlerle tercih ettiklerini göstermektedir. Bu nedenlerin öğretmen adaylarının tercihini etkileme derecesi farklı çalışmalarda farklı sıralamalar halinde ortaya çıkmıştır. Örneğin Bastick'in (2000) çalışmasında bu sıralama dışsal, özgeci ve içsel şeklindeyken, Boz ve Boz (2008) dışsal, içsel ve özgeci şeklinde ve Saban (2003) ise özgeci, dışsal ve içsel şeklinde bir sıralama bulmuşlardır. Bu sıralamanın farklı katılımcılar ve farklı ortamlar ile değişebileceği gibi aynı katılımcıların öğretmen eğitim programının başında ve sonunda belirttiği nedenlerin tercihi etkileme derecesi de değişebilir. Çermik ve diğerleri (2010) öğretmen eğitim programının başında öğretmen adaylarının mesleği tercih nedenlerinin çıkarcı, dışsal, içsel ve özgeci şeklinde sıralandığını ancak aynı katılımcıların öğretmen eğitimin sonunda sırasıyla içsel, çıkarcı, özgeci ve dışsal nedenleri belirttiğini dile getirmişlerdir. Öğretmenlik mesleğinin sağlayacağı faydaların fazla olduğunu düşünen öğretmen adaylarının çoğunlukla dışsal nedenler belirtmesi beklenirken mesleğin sağlayacağı faydaların çok olmadığı yerlerde ise öğretmenlik yapabileceğini düşünen ve bu mesleği seven bireyler öğretmenlik mesleğini tercih etmektedir (Papanastasiou \& Papanastasiou, 1997). Bu çalışmaya katılan öğretmen adaylarının büyük çoğunluğunun öğretmenlik mesleğini yapabileceklerini düşündükleri ya da sevdikleri ve yine aynı oranda çoğunluğun öğretmenlik mesleğinin kendilerine fayda sağlayacağını düşündükleri söylenebilir.

Öğretmen adaylarının meslek tercihinde içsel veya dışsal nedenlerden etkilenme dereceleri içsel ya da dışsal motivasyonları ile ilgilidir. İçsel nedenlerden daha çok etkilenen öğretmen adaylarının içsel motivasyonu yüksektir ve bu öğretmen adayları öğrenmeye açık, öğretmeye karş1 daha olumlu tutumlara sahip ve öğrenmeye yönelik düşük seviyede kaygıya sahiptirler. İçsel motivasyonu yüksek bireylerin düşük olanlara nazaran o etkinliği yapma süreleri daha uzundur (Aktürk, 2012). Katılımc1 öğretmen adaylarının bilinçli bir şekilde bu mesleği tercih ettikleri düşünülmekte ve içsel motivasyonlarının yüksek olduğu düşüncesinden yola çıkarak bu mesleği severek yapacakları ve kendilerini geliştirecekleri beklenmektedir. Ancak özgeci nedenlerden dolayı bu mesleği tercih ettiğini belirten öğretmen adayı oranı içsel ve dışsal nedenlerden dolayı tercih edenlere nazaran oldukça azdır. $\mathrm{Bu}$ durum öğretmen adaylarının mesleği tercih etmede toplum yararını düşünmekten çok bireysel ilgi, beceri ve hedeflerine odaklı oldukları şeklinde yorumlanabilir.

Bu çalışmada diğer çalışmalardan farklı olarak (Aktürk, 2012; Biber, 2013; Boz \& Boz, 2008; Çermik vd., 2010; Hacıömeroğlu \& Şahin-Taşkın, 2010; İncikabı vd., 2016; Yılmaz \& Doğan, 2015) öğretmen adaylarının mesleği tercih nedenleri incelenirken içsel, dışsal ve özgeci nedenlerin altında alt kategoriler oluşturulmuştur. Öğretmen adaylarının meslek tercihlerini etkileyen içsel nedenler incelediğinde öğretmen adaylarının matematik veya öğretmenlik mesleğine yönelik sevgi ya da becerilerinin içsel motivasyonlarını oluşturduğu görülebilir. Öğretmen adaylarının en çok ve en az belirttiği içsel kodlara bakılacak olursa katılımcıların neredeyse yarısına yakını matematiği sevdiklerini belirtmiştir. Benzer şekilde İncikabı ve diğerleri (2016) ile Tataroğlu ve diğerlerinin (2011) çalışmalarında da matematik sevgisi en güçlü içsel neden olarak ortaya çıkmıştır. Ayrıca biyoloji ya da kimya gibi öğretmeyi tercih ettikleri branşı sevme başka çalışmalarda da öğretmenlik mesleğini tercih etme nedeni olarak ortaya çıkmıştır (Boz \& Boz, 2008; Gürbüz \& Sülün, 2004; Sinclair, 2008). Matematik öğrenmeyi sevme ise öğretmen adaylarını en az etkileyen içsel bir neden olarak görülmektedir.

Sosyal ve ekonomik nedenler ya da öğretmenlik mesleğinin sağlayacağı faydaların kişiliklerine uygun olması gibi sebeplerin de öğretmen adaylarının meslek tercihlerini etkilediği söylenebilir. Öğretmen adaylarının dörtte biri üniversiteye yerleştirme puanları bu bölüme yettiği için eğitim fakültesine gelmeyi tercih ettiklerini belirtmişlerdir. Bu azımsanacak bir oran değildir. Puanının yetmesi faktörü pek çok çalışmada (Aktürk, 2012; Boz \& Boz, 2008; Çermik vd., 2010; İncikabı vd., 2016; Olashinde, 1972; Tataroğlu vd., 2011) öğretmen adaylarının tercihlerini etkileyen dışsal faktörlerin başında gelmektedir. Katılımcı öğretmen adaylarının ilk tercihi öğretmenlik olmasa da matematiği sevdiklerinden dolayı bu şekilde bir tercih yaptıkları düşünülmektedir. Ayrıca atanma 
durumu ve diğer mesleklere göre avantajlı bir meslek olarak görülmesi de öğretmen adaylarının tercihlerini etkilemiştir. Bu bulgu Papanastasiou ve Papanastasiou'nun (1997) öğretmenlik mesleğinin sağlayacağı faydaların çokça algılandığı yerlerde bu mesleği tercih nedenlerin çoğunlukla dışsal motivasyon faktörlerinden etkileneceği şeklindeki görüşünü desteklemektedir.

Katılımcı öğretmen adaylarının çok azı öğretmenlik mesleğini niçin tercih ettiğini açıklarken özgeci nedenlerden bahsetmiştir. Öğretmen adaylarının önceden belirlenmiş maddeler içerisinden seçim yapmak yerine açık uçlu sorulara cevap verdikleri için ilk anda özgeci nedenlerin akıllarına gelmemiş olabileceği düşünülmektedir ki bu yorum eğitim fakültelerinde öğretmenliğin özgeci yönlerine de değinilmesi gerektiğine dair ihtiyacı ortaya çıkarmaktadır. Benzer şekilde Çermik ve diğerleri (2010) de öğretmenlik mesleğinin özgeci etkenlerinin düşük bir oranda dile getirilmesinden dolayı bu etkenlere vurgu yapılması gerektiğini önermiştir.

$\mathrm{Bu}$ araştırmanın alt problemlerinden birisi de matematiğin öğretmen adaylarının meslek seçiminde nasıl bir etkisinin olduğunun açığa çıkarılmasıdır. Bu araştırma problemi için elde edilen verilerin analiz edilmesiyle öğretmen adaylarının meslek tercihlerini etkileyen faktörlere benzer ifadeleri yineledikleri görülmüştür. Öğretmen adaylarının yarısından fazlası matematiği sevmelerinin meslek tercihlerini etkilediğini belirtmiştir. Matematikte yetenekli olduğuna ve matematiği anlatabileceğine inanma da öğretmen adaylarının dile getirdikleri ifadelerdendir. Bunun yanı sıra 15 öğretmen adayı $(\% 12,71)$ matematik olmasa öğretmen olmayı düşünmediklerini dile getirmişlerdir. Bu öğretmen adaylarının ifadelerinden matematiğin öğretmen adaylarının meslek tercihleri üzerindeki etkisini daha iyi görebilmekteyiz. Az sayıda öğretmen adayının matematikten dolayı öğretmen olmayı tercih ettiği söylenebilir ki bu durum araştırmanın katılımcılarının büyük çoğunluğunun öğretmenliği sevdikleri şeklinde de yorumlanabilir.

Matematik sevgisi, matematikte başarılı olduğuna dair inanç ve atanma ihtimalinin yüksek olması gibi nedenlerin her iki soruya verilen cevaplarda ortaya çıkması bu nedenlerin öğretmen adaylarının meslek tercihlerini etkileyen başlıca faktörler olduğu anlamına gelebilir. Öğretmen adaylarının pek çok kez matematiği sevdiklerini ve matematik öğretmenliğini yapabileceklerine dair inançlarını dile getirmeleri beklenti-değer teoremi kapsamında bu mesleği gerçekleştirmeye yönelik ısrar, süreklilik ve enerjiye sahip olmaları şeklinde yorumlanabilir (Wigfield \& Eccles, 2000). Öğretmen adaylarının ikinci soruya verdiği cevaplar incelendiğinde öncelikli tercihi öğretmenlik olmayan adayların matematiği sevdikleri, öğretebileceklerine inandıkları ve başarılı olduklarını düşündükleri için "matematik öğretmeni” olmaya karar verdikleri görülmeltedir. Matematiğin tercihleri üzerinde etkisi olmadığını düşünen öğretmen adaylarının bir kısmının ideallerindeki mesleğin zaten öğretmenlik olduğu görülürken bir kısmının da öğretmenliği isteyerek seçmemiş oldukları ve matematiği aslında sevmedikleri görülmektedir.

Son olarak matematik öğretmeni olma fikrinin öğretmen adaylarına hissettirdiği duygular incelenecek olursa en çok dile getirilen üç duygu mutluluk, heyecan ve güzel hisler olarak görülmektedir. En çok dile getirilen olumsuz his ise kaygı-korku duygusu olsa da öğretmen adaylarının $\% 11$ 'i bu duyguyu ifade etmiștir. Korku-kaygı gibi olumsuz duyguların az oranda ortaya çıkması öğretmen adaylarının genelde kendilerine güvendikleri şeklinde yorumlanabilir. $\mathrm{Bu}$ bulgular doğrultusunda öğretmen adaylarının seçimlerinden dolayı mutlu olduklarını ancak yine de nasıl bir öğretmen olacağına dair kaygı duyanların da bulunduğu görülmektedir.

Tüm sorulardan elde edilen bulgular bir arada ele alındığında katılımcı öğretmen adaylarının çoğunlukla matematiği sevmelerinden dolayı bu bölüme isteyerek ve bilinçli bir biçimde geldikleri ve burada olmaktan mutlu oldukları söylenebilir. Ancak öğretmen adaylarının öğretmenlik mesleğinin aynı zamanda fedakârlık gerektiren bir meslek olduğuna dair vurgulara da ihtiyacının olduğu sonucuna ulaşılabilir. Bu çalışmada öğretmen adaylarının cevapları hiçbir değişken göz önüne alınarak ayrı ayrı incelenmemiştir. Ancak ilerleyen zamanlarda yapılacak çalışmalarda öğretmen adaylarının sınıf seviyesi, cinsiyeti, öğretim deneyimine sahip olup olmadıkları ya da bu bölümün kaçıncı tercihleri olduğu gibi değişkenlere göre öğretmen adaylarının tercih nedenleri incelenebilir. Bunun yanı sıra verilerin yalnızca yazılı bir görüşme formu ile toplanması da bu çalışmanın sınırlılıklarındandır. Öğretmen adaylarının meslek tercihlerinin altında yatan temel faktörler açığa çıkarılamamış olabilir. Bu nedenle açık uçlu soru formlarının yanı sıra yüz yüze görüşmeler de yapılarak öğretmen adaylarının öğretmenlik mesleğine ilişkin düşünceleri daha detaylı bir biçimde ele alınabilir. 


\section{KAYNAKÇA}

Akbaba, S. (2006). Eğitimde motivasyon. Kazım Karabekir Eğitim Fakültesi Dergisi, 13, 343-361.

Aktürk, A. O. (2012). Öğretmen Adaylarının Öğrenmeye İlişkin Tutumlarının Öğretmenlik Mesleğini Tercih Etme Nedenlerine ve Akademik Başarılarına Göre İncelenmesi. Ahi Evran Üniversitesi Kırşehir Eğitim Fakültesi Dergisi (KEFAD), 13(3), 283-297.

Argun, Y. (2003). Eğitim Fakültesi Okulöncesi Eğitim Programında Devam Eden Öğrencilerin Mesleği Seçme Nedenlerinin Karşılaştırılmalı Olarak İncelenmesi. Eğitim Araştırmaları Dergisi, 13(4), $22-28$.

Aydın, R., \& Sağlam, G. (2012). Öğretmen Adaylarının Öğretmenlik Mesleğine Yönelik Tutumlarının Belirlenmesi (Mehmet Akif Ersoy Üniversitesi Örneği). Türk Ĕgitim Bilimleri Dergisi,10(2),257-294.

Bastick, T. (2000). Why Teacher Trainees Choose the Teaching Profession: Comparing Trainees in Metropolitan and Developing Countries. International Review of Education, 46(3-4), 343-349.

Biber, A. Ç. (2013). Öğretmen Adaylarının İlköğretim Matematik Öğretmenliği Lisans Programı Hakkındaki Memnuniyet Düzeylerinin Araştırılması: Kastamonu Üniversitesi Eğitim Fakültesi Örneği. Kastamonu Ĕgitim Dergisi, 21(3), 1253-1270.

Bowles, M. A. (2010). The think-aloud controversy in second language research. London: Routledge.

Boz, Y., \& Boz, N. (2008). Kimya ve Matematik Öğretmen Adaylarının Öğretmen Olma Nedenleri, Kastamonu Eğitim Dergisi, 16(1), 137-144.

Brown, M. M. (1992). Caribbean First-Year Teachers' Reasons for Choosing Teaching as A Career. Journal of Education for Teaching, 18(2), 185-195.

Bursal, M., \& Buldur, S. (2013). Fen Bilgisi Öğretmen Adayları İçin Öğretmenlik Tercih Nedenlerini Derecelendirme ve Geleceğe Yönelik Beklentiler Ölçekleri Geliştirme Çalışması. Turkish Journal of Teacher Education, 2(1), 47-64.

Büyüköztürk, Ş., Kılı̨̧ Çakmak, E., Akgün, Ö. E., Karadeniz, Ş., \& Demirel, F. (2010). Bilimsel araştırma yöntemleri (7. Baskı). Ankara: Pegem Yayınları.

Carter, G., \& Norwood, K. S., (1997). The Relationship Between Teacher and Student Beliefs About Mathematics. School Science and Mathematics, 97(2), 62-67.

Christensen, L. B., Johnson, B., \& Turner, L. A. (2011). Research methods, design, and analysis. Pearson: New York.

Creswell, J. W. (2007). Qualitative inquiry and research design: Choosing among five approaches. Thousand Oaks, CA: Sage.

Çapraz, C., \& Sabancı, O. (2014). Sınıf Öğretmeni Adaylarının Öğretmenlik Mesleğine Yönelik Görüşleri ve Okul Deneyiminin İlk Gününde Hissettikleri Duygular. Atatürk Üniversitesi Sosyal Bilimler Enstitüsü Dergisi, 18(1), 179-188.

Çermik, H., Doğan, B., \& Şahin, A. (2010). Sınıf Öğretmenliği Öğretmen Adaylarının Öğretmenlik Mesleğini Tercih Sebepleri, Pamukkale Üniversitesi Ĕ̈itim Fakültesi Dergisi, 28(2), 201-212.

Dawson, V. (2007). Factors influencing pre-service teachers' decisions to become secondary science and mathematics teachers. Teaching Science: The Journal of the Australian Science Teachers Association, 53(4), 28-31.

Evans, H. (1993). The Choice of Teaching as a Career. Social and Economic Studies 42(2/3), 225-242.

Ford, M. I. (1994). Teachers' Beliefs About Mathematical Problem Solving in The Elementary School. School Science and Mathematics, 94(6), 314-322.

Ginzberg, E., Ginsburg, S. W., Axelrad, S., \& Herma, J. L. (1951). Occupational choice: An approach to a general theory. New York: Columbia University Press.

Gürbüz, H., \& Kışoğlu, M. (2007). Tezsiz Yüksek Lisans Programına Devam Eden Fen-Edebiyat ve Eğitim Fakültesi Öğrencilerinin Öğretmenlik Mesleğine Yönelik Tutumları (Atatürk Üniversitesi Örneği). Erzincan Eğitim Fakültesi Dergisi, 9(2), 71-83

Gürbüz, H., \& Sülün, A. (2004). Türkiye' de Biyoloji Öğretmenleri ve Biyoloji Öğretmen Adaylarının Nitelikleri. Milli Eğitim Dergisi, 161,193-199.

Hacıömeroğlu, G., \& Şahin-Taşkın, Ç. Ş. (2010). Fen Bilgisi Öğretmenliği ve Ortaöğretim Fen ve Matematik Alanları (OFMA) Eğitimi Bölümü Öğretmen Adaylarının Öğretmenlik Mesleğine İlişkin Tutumları. Ahi Evran Üniversitesi Eğitim Fakültesi Dergisi, 11(1), 77-90. 
Hayes, S. (1990). Students' Reasons for Entering the Educational Profession, Research Report (35 pp.). Oklahoma: North-western Oklahoma State University.

İncikabı, L., Mercimek, O., Biber, A. Ç., \& Serin, M. K. (2016). Neden İlköğretim Matematik Öğretmenliği Programındayım? Tercih Nedenleri ve Beklentilerin Cinsiyet ve Akademik Başarı Bağlamında İncelenmesi: Kastamonu Üniversitesi Örneği. Necatibey Eğitim Fakültesi Elektronik Fen ve Matematik Ë̆itimi Dergisi, 10(2), 367-390.

İşmen, A. E., \& Yıldız, S. A. (2005). Öğretmenliğe İlişkin Tutumların Özgecilik ve Atılganlık Düzeyleri Açısından İncelenmesi. Kuram ve Uygulamada Ĕ̈itim Yönetimi, 42(42), 151-166.

Kartal, T., \& Taşdemir, A. (2012). Fen Bilgisi Öğretmen Adaylarının Öğretmenlik Mesleğine İlişsin Görüşleri. Abant İzzet Baysal Üniversitesi Ĕ̈itim Fakültesi Dergisi. 12(2), 73-96.

Kyriacou, C., \& Coulthard, M. (2000). Undergraduates' Views of Teaching as A Career Choice. Journal of Education for Teaching, 26(2), 117-126.

Miles, M. \& Huberman, A. M. (1994). Qualitative Data Analysis. Beverly Hills, California: Sage.

Milli Eğitim Bakanlığı (MEB, 2017). http://oygm.meb.gov.tr/meb_iys_dosyalar/2017_12/11115355_YYRETM ENLYK_MESLEYY_GENEL_YETERLYKLERY.pdf

Moustakas, C. (1994). Phenomenological research methods. Thousand Oaks, CA: Sage.

Ngoepe, M. G. (2014). Student Teachers' Motives of Becoming Mathematics Teachers: An Exploratory Study. International Journal of Educational Sciences, 6(2), 297-307.

Olashinde, M. O. (1972). An Analytical Study of the Motives of Primary School Teachers for Choosing Teaching as a Career. Journal of Teacher Education, 23(2), 207-210.

Övet, O. (2006). Ĕ̌̆itim Fakültesi Öğrencilerinin Öğretmenlik Mesleğini Tercih Etmelerinde Etkili Olan Faktörlerin Belirlenmesi, Yayınlanmamış Yüksek Lisans Tezi, Yeditepe Üniversitesi, Sosyal Bilimler Enstitüsü, İstanbul.

Özbek, R. (2007). Öğretmen Adaylarının Öğretmenlik Mesleğini Tercih Etmelerinde Kişisel, Ekonomik ve Sosyal Faktörlerin Etkililik Derecelerine İlişkin Algıları. Fırat Üniversitesi Sosyal Bilimler Dergisi, 17(1), 145159.

Özbek, R., Kahyaoğlu, M., \& Özgen, N. (2007). Öğretmen Adaylarının Öğretmenlik Mesleğine Yönelik Görüşlerinin Değerlendirilmesi. Sosyal Bilimler Dergisi, 9(2), 221-232.

Özder, H., Konedralı, G., \& Zeki, C. P. (2010). Öğretmen Adaylarının Öğretmenlik Mesleğine Yönelik Tutumlarının Çeşitli Değişkenler Açısından İncelenmesi. Kuram ve Uygulamada Eğitim Yönetimi, 16(2), 253-275.

Papanastasiou, C., \& Papanastasiou, E. (1997). Factors that influence students to become teachers. Educational Research and Evaluation, 3(4), 305-316.

Plano Clark, V. L., \& Creswell, J. W. (2015). Understanding research: A consumer's guide. Upper Saddle River, NJ: Pearson Education.

Saban, A. (2003). Sınıf Öğretmeni Adaylarının Demografik Özellikleri ve Mesleki Eğilimleri. Ĕgitim Araştırmaları Eurasian Journal of Educational Research, 10, 91-101.

Sağlam, Ç. A. (2008). Müzik Öğretmenliği Bölümü Öğrencilerinin Öğretmenlik Mesleğine Yönelik Tutumları. Yüzüncü Yıl Üniversitesi Eğitim Fakültesi Dergisi, 5(1), 59-69.

Sinclair, C. (2008). Initial and Changing Student Teacher Motivation and Commitment to Teaching. Asia-Pacific Journal of Teacher Education, 36(2), 79-104.

Smith, O. (1986). A Design for A School of Pedagogy. Washington, DC: US Department of Education.

Tataroğlu, B., Özgen, K., \& Alkan, H. (2011). Matematik Öğretmen Adaylarının Öğretmenliği Tercih Nedenleri ve Beklentileri. $2^{\text {nd }}$ International Conference on New Trends in Education and Their Implications. Ankara: Siyasal Kitabevi, (998-1006).

van Manen, M. (1990). Researching lived experience: Researching lived experience. Albany, NY: State University of New York Press

Wigfield, A., \& Eccles, J. S. (2000). Expectancy-value theory of achievement motivation. Contemporary Educational Psychology, 25(1), 68-81.

Yenice, N., \& Özden, B. (2017). Pedagojik Formasyon Sertifika Programına Katılan Biyoloji Öğretmen Adaylarının Öğretmenlik Mesleğine Yönelik Görüşleri. Düzce Üniversitesi Sosyal Bilimler Enstitüsü Dergisi, 7(2), 89-105. 
Yıldırım, A. ve Şimşek, H. (2008). Nitel Araştırma Yöntemleri (7. Baskl). Ankara: Seçkin Yayıncılık

Yılmaz, N., \& Doğan, N. (2015). İlköğretim Matematik Öğretmen Adaylarının Meslek Tercihlerini Etkileyen Faktörler: Hacettepe Üniversitesi Örneği. Abant İzzet Baysal Üniversitesi Eğitim Fakültesi Dergisi, 15(1), 405-421.

Yong, B. (1995). Teacher Trainees' Motives for Entering into a Teaching Career in Brunei, Darussalam. Teaching and Teacher Education, 2(3),275-280. 